\title{
Students' Reflective Journals and Creative Writing in EFL
}

\author{
Haya Abdul Rahman Abu Hussein ${ }^{1, *}$, Deena Abdul Hameed Al Jamal ${ }^{2}$, Imad Sadi \\ ${ }^{1}$ Department of Languages and Translation, Faculty of Arts, Birzeit University, Palestine \\ ${ }^{2}$ Department of Curriculum and Methods of Teaching, Faculty of Education, Yarmouk University, Jordan
}

Received April 28, 2020; Revised June 2, 2020; Accepted July 1, 2020

Copyright $\mathrm{O} 2020$ by authors, all rights reserved. Authors agree that this article remains permanently open access under the terms of the Creative Commons Attribution License 4.0 International License

\begin{abstract}
This study aimed at investigating the effectiveness of online reflective journals on Birzeit University students' creative writing. The participants of the study were sixty first-year university students. They were chosen randomly from Birzeit University in the second semester of the academic year 2019/2020. The study followed the quasi-experimental design. The participants were divided into two groups: an experimental group $(n=30)$ and a control group $(n=30)$. To carry out the study, the researcher taught her students how to write reflective journals, and she established a closed group on Messenger for her students to write their online reflective journals and share them on the group frequently each time on a different topic. The data about the students' creative writing skills were collected using a creative writing pre/post-test designed by the researcher. The data were analyzed using appropriate quantitative analyses. The results of the study showed that the proposed instructional strategy was effective in improving students' creative writing skills. The results proved that the strategy of online reflective journals has positively affected the components of creative writing (originality, flexibility, fluency, and elaboration).
\end{abstract}

Keywords Online Reflective Journals, Creative Writing, Originality, Flexibility, Fluency, Elaboration

\section{Introduction}

Writing is a fundamental language skill that is of high importance as a means for communicating ideas, emotions, and thoughts. It is accentuated with other language skills, namely, reading, listening and speaking. Learners start their academic journey with this skill at an early age since it cannot be separated from other skills. Despite the long years of teaching and learning writing, this skill is still seen as a problem for many learners. They perceive it as complicated and challenging. A further challenge that tutors face while teaching writing is how to make their students enjoy the process and live it with all their feelings, emotions, and imagination to express their ideas freely and creatively.

According to Randolph (2011), challenges that EFL learners face when they write may entail a- being asked to write in an unpleasant or undesirable style that makes them uncomfortable, b- having to write on unattractive or uninteresting topics, c- elaborating on ideas in coherent paragraphs. Yet, the key to solving these problems can be seen through creative writing. In creative writing students are given the free choice to write on the topics they love, they are not restricted with one style or form of writing. Here, learners unleash their imagination to think, meditate, interact, create, and elaborate freely without any restrictions. In addition to the pleasure creative writing brings to the process of writing, it can enhance learners' cognitive and communicative skills (Cristopher, 1996).

Creative writing has been defined as the art of producing fictional narratives e.g. short stories, poems, novels, etc. or written representations (Nettle, 2009). Other scholars added nonfiction writing like writing essays, articles, etc. (Root \& Steinberg, 1999). Specifically, Chen and Zhou (2010) define it as an open-ended process that can enhance children's thinking skills and can add to their creativity. Larkin (2009) considers creative writing as a craft, not just a passion.

Creative writing includes the following key components: a- originality, which means the ability to produce new ideas; b- fluency, which is mainly about being able to produce ideas easily and smoothly, c- flexibility, which indicates the ability to generate a wide range of different ideas, $d$ elaboration, which means the ability to add more details to the main ideas (Torrance, 1996). Effective teachers try to find effective writing methods and strategies to promote creative writing skills. One strategy that involves making 
learners write without restrictions and can enhance using their ideas freely is reflective journals (Davies, 1995).

According to Kelly and Gargagliano (2001), the process of writing is similar to play a musical instrument; it needs much practice to master. Interestingly, one way of practice is through writing online reflective journals. The research pointed out the significance of using reflection on improving students' creative writing skills (Chen, Wei, Wu \& Uden, 2009). Additionally, it has been also important to help students improve personally and professionally (Dyment \& O’Connell, 2011).

Reflective writing has its deep roots in several learning theories. For example, Dewy (1933) introduced interactionist and reflective thinking theories. He recommended introducing learning experiences in order to enhance meaningful learning. For him, effective learning happens when learners become truly engaged in the content in a personal way. Experiential learning is an essential aspect of engaging learners. In addition, Kolb (1984) created a four-stage model that leads to effective learning. Active experimentation, abstract conceptualization, reflective observation, and concrete experience are important stages, which are involved in that model. In this model, learners may begin at any stage and then follow the sequence.

Individual reflection may improve learner's insights, enhance critical thinking, and promote his/her cognitive awareness (Andrusyszyn \& Davie, 1995). In a conference paper in 1997, Andrusyszyn and Davie explained how critical thinking could facilitate reflection as the means of interactive journal writing. Their paper demonstrated that the personal learning process could be stimulated through dialogue with oneself or with one's instructor over time. In order to be able to start using reflective writing, students should first be introduced to the reflective thinking, which is vital to identifying classroom problems and help to analyze and give possible solutions to such problems (Spalding \& Wilson, 2002). Of course, learners should be able to differentiate between telling and reflecting. They need to learn pedagogical strategies related to reflective thinking (Bolin, 1990; Krol, 1996).

Reflective thinking is a cognitive process and a key feature in reflective journals can help students to think deeply and meditate on their learning. It allows students to consider their experiences, decisions, and actions so that they can recognize the values and beliefs behind their actions and decisions. This will eventually lead them to consider any related results and consequences (Sumsion \& Fleet, 1996). It also helps in building up their confidence and autonomy. This is because reflective thinking takes into high consideration students' thoughts and perceives them of high value. It likewise helps to decrease stress and anxiety related to the classroom environment (McGuire, Lay \& Peters, 2009).

\subsection{Statement of the Problem}

Being a teacher of the English language and a university instructor for more than fourteen years, the researcher noticed that undergraduate students face difficulties in writing classes. Their major problem is so apparent when conveying ideas. Many students tend to rely on memorizing certain written formats instead of improving their own skills in writing. Eventually, because of this, the researcher has noticed that students' attitudes towards writing are negative. They always complain to their teacher about the boredom they suffer while writing. Potentially, this has affected their academic achievements in writing exams and assignments.

The researcher noticed that little research has been conducted in the Palestinian context on using online reflective journals with reference to creative writing development. The researcher believes that the role of technology can be maximized in order to improve students' creative writing, which may, in turn, enhance their overall language achievement.

\subsection{Purpose of the Study}

This study aims to investigate the effect of using online reflective journals on improving the creative writing skills of Birzeit University students' creative writing and it aims at investigating their attitudes towards it.

\subsection{Research Question}

Are there any statistically significant differences in creative writing skills attributed to the instructional strategy (online reflective journals vs. the conventional)?

\subsection{Significance of the Study}

This study is significant as it is hoped to give important insights to stakeholders at the Ministry of Education and Higher Education, as well as to practitioners in the field of teaching on the significance of using reflective writing as an effective strategy to improve students' writing skills. It is also expected to enhance using technology to improve students' creative writing skills. It is worth mentioning that, to the best of the researcher's knowledge, this study may be one of the few that has investigated using online reflective journals on improving creative writing skills in EFL teaching at Palestinian universities.

\subsection{Reflective Writing}

According to research carried out in 2008 by the Learning Center, The University of New South Wales, it is relevant to responses obtained by one's experiences, opinions, events, thoughts, feelings, or knowledge. Therefore, it is a way of thinking where one has an opportunity to gain self-knowledge. To this end, a better understanding of learning reinforcement can be achieved. In this study, reflective writing is meant to be an interactive way through which students meditate, think deeply, ask 
questions, and give their own reflections on their learning experience by writing online journals on assigned topics. Reflective writing is the students' own way to express their feeling about what they learn freely and creatively.

\subsection{Online Journals}

According to Rusli and Sutopo (2019) an electronic or online journal can be defined as a periodical publication, which is published in electronic format, usually on the Internet. In this study, online journals are students' online-shared essays in response to assigned paragraphs. The researcher chose particular topics that are related to the ones in their textbooks every week and sent them through a messenger group to all students. The social media means used in this study is the Messenger App. Here, students can write at their comfort, and get feedback immediately on their work.

\subsection{Creative Writing}

Creative Writing is an important form of communication that allows students to present their ideas, thoughts, and feelings freely by using their imagination without any restrictions on paper. In this study, the researcher intended to improve creative writing skills including originality, fluency, flexibility, and elaboration.

\section{Originality:}

In this study, originality stands for students' ability to generate new and novel ideas by using their imagination while writing. It is one of the sub-skill of creative writing;

Fluency: the second sub-skill in creative writing means the ability to express one's ideas, feelings, and emotions easily and articulately.

Flexibility: the third sub-skill in creative writing stands for students' ability to change their ideas or adapt them accordingly and to look at things or topics from different angles;

Elaboration: the fourth sub-skill in creative writing refers to students' ability to explain their ideas with more details (facts, definitions, concrete details, quotations, and informative examples).

\section{Literature Review and Hypotheses Development}

\subsection{Reflective Writing}

According to Houston (1988), the history of reflection goes back to Plato, Aristotle, Confucius, and Buddha. Those great philosophers were mainly concerned with reflective thinking. Reflection in education was launched firstly in the 1930s by John Dewy. Schon (1987) explained reflective thinking differently as a kind of conversation that happens between action and thought. Explicitly, Shulman (1987) elaborated on the term by identifying its processes of "reviewing, reconstructing, reenacting, and critically analyzing one's own and the class's performance, and grounding explanations in evidence" (p. 15). Bolton (2005) believed that reflective practice could be defined as the practice that is based on understanding, explaining values and beliefs, this assumption is based on the constructivism theory in learning as both of constructivism, and reflection can contribute to improving teaching and learning practices. Lew and Schmidt (2011) observe self-reflection as a process done by the learner when he/she goes back to what they experienced in the past. They believe that better academic achievement can be reached by consistent practicing of self-reflection on the learning process.

Reflective thinking is also perceived as a process that both teachers and learners should go through and practice very often to improve their teaching and learning processes (Risko, Roskos, \& Vukelich, 2002). Rodgers (2002) asserted that teachers need to obtain some important skills so that they can build their capacities in decision-making based on their experiences. Shulman (1987) stated that reflection in education is a process in which learners review, reconstruct, reenact, and analyze the class performance critically with grounded explanations.

Schon (1983), in his book The Reflective Practitioner, shed the light on two important stages of reflection, these are reflection-in-action and reflection-on-action. The first stage involves reflecting and responding to a situation directly at the moment and react directly to the situation. The second stage takes place after the event or the experience and it requires looking back at the situation, mediating at their practices, and evaluating them carefully so that in the future practitioners can improve their practices, avoid previous mistakes and put prospective plans to improve their actions. Killion and Todnem (2001) explained reflection-for-action in which a person is expected to interpret the situation he went through, makes inferences, and becomes reflective in a critical way so that he/she can gain different perspectives. The effective role of diaries to improve university students' reflective practice was discussed by Hubbs and Brand (2005). Hubbs and Brand (2005) stated that reflective journals could help students develop automatic thinking and the habits of mind and lead them towards a transformative process when engaged in mutual dialogue by their teacher.

In the age of social media, it is fundamental to integrate reflective journals in the educational process. Studies were conducted to find out more about the prospective positive outcomes of writing blogs, wikis, online or electronic journals (McLoughlin \& Lee, 2007). Some researchers posed important questions concerning engaging students in writing online. For example, Klages and Clark (2009) showed their concerns in relation to students' abilities to switch between using technology with their friends and using it for academic purposes. That's why it has become 
essential to focus more on research on using online reflective journals.

\subsection{Creative Writing}

Emig (1977: 123) defined writing as "originating and creating a unique verbal construct that is graphically recorded." According to Hedge (2000: 124), writing requires students to learn several skills including deciding their goals, producing ideas, regulating information, selecting an appropriate language, drafting, revising, and emending. It includes a complicated process for second language authors, as it is not easy or spontaneous.

Creativity is defined by Boden (2001) as the ability of generating new ideas which are unexpected, understandable, and worthy. Kaplan (2019) believed that creativity is important to innovation, modernity, and sustenance. Creative writing has importance since it helps learners to discover the true value of the writing and can help to improve reading and writing skills (Essex, 1996; Shanahan, 2006). Creative writing is likewise introduced as an open-ended design process that constructs on creativity and is related to the thinking skill development of children (Chen \& Zhou, 2010). Larkin (2009) believes that creative writing exceeds passion to become a craft for practicing individual writing awareness and following effective writing processes to come out with written texts.

\subsection{Creative Writing Skills}

Karuri (2012, p.77) defined creative writing skills as the capabilities that facilitate the students and prepare their ideas into words during a purposeful and logical kind supported four creative scopes specifically flexibility, elaboration, proficiency, and fluency. According to Cramar (2003), creative writing skills can help students to express themselves, their ideas, emotions, and feelings. Creative writing can be students' tools to turn their creative imagination into words. It also allows them to reflect on their experiences in a new and different way. That is why creative writing is always looked at as an essential way for improving students' writing skills. Some experts have believed that creativity is an inborn ability and has nothing to do with learning (Donnvan, 2007). However, others have rejected this assumption and have asserted that creativity can be taught with careful gearing and constant encouragement. This means that teachers can provide essential instruction to improve their students' creativity (Barbot, et al, 2012).

Christopher (1996) thinks that creative writing is characterized by originality, flexibility, accuracy, imagination, and organization. Creative writing can take the form of stories, poetry, playwright, and dialogue.

According to Brookes and Marshall (2004), creative writing is characterized by the following characteristics; these are originality, fluency, flexibility, and elaboration.
Fluency involves the ease and speed that can help a creative person retrieve information from memory. It means the ability to generate ideas that are relevant to the topic of writing. The second skill is originality, which stands for the writer's ability to produce new and original ideas that are innovative and unique. The third skill is flexibility, which involves the ability to come out with different ideas that can support the main topic. Finally, elaboration means the ability to expand in detail by providing more details and analysis (Starko, 2005). Chandio, Khan, and Samiullah (2013) explained that creative writing is based on using the skill of imaginative thinking to produce new ideas and using the mental skills to generate new ideas fluently and flexibly. These ideas should be novel and imaginative.

\subsection{Empirical Studies}

Branch (2010) investigated the effectiveness of reflective practice and reflective journals on enhancing humanistic qualities and communicative skills for medical students, young faculty members, professionals, and other workers in the health field. The study followed a qualitative longitudinal process over a twenty-two period. The researcher analyzed the detailed descriptions and reflections. The results showed that the educational programs based on reflective practice including longitudinal learning in small groups, creating a support group process, prominent inclusion of reflective learning and experiential learning have led to significant results in enhancing humanistic values and can have more transformative impacts on learners. The results of this study and its effects can be taken seriously for future educational efforts to enhance humanistic professionals.

Liao and Wong (2010) conducted a study to investigate the effectiveness of conversation journals on foreign language learners' writing fluency, reflections, anxiety, and motivation. The study's sample included forty-one tenth-grade students in Taiwan. Each one of these students was asked to write twenty-four journals at two journal entries weekly. The study consisted of 984 journals written by students, open-ended questions, and interviews in addition to the results of pre/post-study questionnaires and a pre- posttest on the students' writing skills and performance. The results showed how dialogue journal writing enhanced writing fluency, reflective thinking skills, and increased intrinsic motivation. The (DJW) helped also reduced writing anxiety. Moreover, the students' attitudes towards (DJW) as this strategy enhanced self-understanding and self-growth. Students declared that (DJW) enhanced their self-confidence, which has helped them get along better with each other and matured them as they kept sharing their ideas, feelings, and self-perceptions. Students' confidence in English writing was enhanced by their daily reflection.

Farrah (2012) evaluated the effect of reflective journals on improving the writing process, increasing motivation, 
and enhancing creativity and critical thinking. The study was conducted at Hebron University on a sample of 120 male and female university students from four sections of writing sections. To collect the data, a 19-item questionnaire was distributed and the items were varied according to three main dimensions: improving learning, motivation, self-confidence, and value and convenience. The results indicated that writing reflective journals have positive results in improving the writing process and enhancing students' motivation, self-confidence, and creativity.

Sidek and Yunus (2012) investigated students' experiences in using blogs as learning journals. The study was conducted on 60 students from the COM2033 (Public Speaking) course at MARA Professional College in Malaysia. The study followed the qualitative design to collect data through observing students' journal entries and comments, in addition to interviewing 6 students to get more perspectives about students' experiences in writing blogs as learning journals. The results showed that students enjoyed the process of writing blogs in their lessons. Moreover, they indicated that they wish if this strategy can be used more widely in learning. The findings also revealed students' recommendations to improve the use of blogging through their experiences.

Annamalai and Jaganathan (2017) investigated the effect of online reflective writing on improving reflective thinking and writing skills. Six students and a teacher from an urban school in Northern Malaysia were engaged in the study. The researchers followed Garrison et al.'s (2000) to categorize qualitative data in the form of online archives as reflection-in-action, which focused on giving feedback and self-correction. Later they focused on reflection-on-action, which was based on students' reflective journals that demonstrated their thoughts and feelings while engaged in the Facebook environment. The results showed that reflective journals on Facebook could be considered as a successful platform to improve students' narrative writing skills.

\section{Method}

\subsection{Design}

The study followed a quasi-experimental research design. The students were allocated into two groups, one group was assigned randomly as experimental and the other as a control. They were examined to determine the potential effectiveness of the variables of the research. The study had one independent variable that is the online reflective journals, whereas the dependent variables are the students' creative writing skills.

\subsection{Participants of the Study}

The participants of the study were chosen purposefully to the researcher who works as a lecturer of English language at Birzeit University. They consisted of sixty freshmen students (almost 19 years old). They were from different university specializations and courses and from both genders (males and females). These students were randomly assigned into two groups (experimental and control). Students in the two sections were subjected to pre-/ post-test to assess their creative writing skills. The experimental section was trained on writing reflectively and practice writing through online journals; a group on the Messenger app was created for this particular reason, where the researcher used to assign a writing task to be done frequently, while the control section was not given any treatment.

Table 1. Distribution of the Participants

\begin{tabular}{|c|c|}
\hline Group participants of the study & $\mathrm{n}$ \\
\hline Experimental & 30 \\
\hline Control & 30 \\
\hline Total & 60 \\
\hline
\end{tabular}

\subsection{The Instrument}

The pre/ post-test was designed to show the main creative writing skills that the research intended to improve. The pre/posttest was mainly a writing task (writing an essay), where students were asked to write about a problem they suffer from in their city, town, village, neighborhood, or in university, this problem could be educational, social or environmental; they were asked to describe that problem and suggest some possible solutions to that problem. The pre/posttest focused on investigating the creative writing skills of originality, flexibility, fluency, and elaboration. The pre-test aimed at evaluating students' writing skills before and after conducting the research and using the intended teaching strategy of online reflective journals for eight weeks on students at Birzeit University. The post-test was carried out after the period of research finished seeing whether there were any statistically significant results attributed to the teaching strategy of using online reflective journals on improving students' creative writing.

\subsection{Duration of the Study}

This study lasted for two months, for eight weeks, two writing periods each week. The study was carried in the second semester in the academic year 2019-2020. The instructional material, which was used in the study, was the Unlock B1 textbook.

\subsection{Item Difficulty and Item Discrimination}

The difficulties and the discriminations for the test components sub-skills were extracted. It has been piloted to a sample of 16 participants. Table (2) illustrates the difficulties and the discrimination indices of the test components sub-skills. 
Table 2. Summary Results of Difficulties and Discriminations Indices for The Test Components Sub-skills

\begin{tabular}{|c|c|c|c|}
\hline Creative Component & Sub-skills & Item Difficulty & Item Discrimination \\
\hline \multirow{2}{*}{ Originality } & $\begin{array}{l}\text { Generate unique ideas without particular care whether these } \\
\text { ideas will be useful or not (ORIG-S-1). }\end{array}$ & .39 & .39 \\
\hline & $\begin{array}{l}\text { Recommend alternatives solutions for the ideas in the } \\
\text { book-writing topic (ORIG-S-2). }\end{array}$ & .55 & .65 \\
\hline \multirow{3}{*}{ Flexibility } & Generate opinions from different perspectives (FLEX-S-1). & .45 & .60 \\
\hline & Provide alternative endings to the conclusion (FLEX-S-2). & .54 & .63 \\
\hline & $\begin{array}{l}\text { Suggest alternative procedures and recommendations } \\
\text { (FLEX-S-3) }\end{array}$ & .47 & .41 \\
\hline \multirow{2}{*}{ Fluency } & $\begin{array}{l}\text { Write several phrases and expressions with synonyms and } \\
\text { antonyms for the words in the writing subject (FLUE-S-1). }\end{array}$ &. .39 & .44 \\
\hline & Generate reasoning ideas (FLUE-S-2). &. .41 & .51 \\
\hline \multirow{2}{*}{ Elaboration } & $\begin{array}{l}\text { Expand on the details of the topic to explain and embellish } \\
\text { upon ideas (ELAB-S-1). }\end{array}$ & .46 & .55 \\
\hline & $\begin{array}{l}\text { Broaden and extend the importance of the writing topic } \\
\text { (ELAB-S-2). }\end{array}$ & .51 & .57 \\
\hline
\end{tabular}

As we can see in Table (2), the discrimination indices for the fourth component sub-skills ranged from .39 to .55 , and all in the acceptable value (Odeh, 2010). Further, the difficulties indices for the fourth component sub-skills ranged from .39 to .65 and all in the acceptable value (Odeh, 2010).

\subsubsection{Face validity}

To verify the face validity of the test, the test has been presented to a panel of experts in Palestinian and Jordanian universities who specialize in English language curricula and teaching methods. Based on the experts' comments, the content of the test has not been modified or drafted.

\subsubsection{Reliability}

To verify test-retest reliability, the test administered to the pilot sample two times, and Pearson Correlation Coefficients were extracted. Furthermore, to verify the internal consistency, Cronbach alpha approach was employed. Table (3) illustrates test-retest reliability and Cronbach alpha coefficients for each component of the creativity test and the whole test.

Table 3. Summary Results of Test-retest Results

\begin{tabular}{ccc}
\hline Component & Test-retest Coefficient & Alpha Coefficient \\
\hline Originality & .71 & .75 \\
Flexibility & .80 & .79 \\
Fluency & .84 & .86 \\
Elaboration & .76 &. .73 \\
Total & .95 & .89 \\
\hline
\end{tabular}

Table (3) shows that the test-retest reliability index for originality, flexibility, fluency, elaboration, and the entire test (total), were, $.71, .80, .84, .76$, and .95 , respectively. Also, Cronbach alpha reliability index for originality, Flexibility, Fluency, Elaboration, and the entire test (total), were, $.75, .79, .86, .73$, and .89 , respectively. As such, the test is reliable (Odeh, 2010).

Furthermore, to verify the internal consistency (validity) for the test, the Pearson correlation coefficient for the fourth component of the test with a total score of the test was extracted. Table (4) illustrates Pearson correlation coefficient for the four creativity components of the test with a total score of the test.

Table 4. Correlation Coefficient for the Fourth Components of the Test with Total Score of the Test

\begin{tabular}{ccc}
\hline Component & $\begin{array}{c}\text { Pearson Correlation } \\
\text { Coefficient }\end{array}$ & $\begin{array}{c}\text { Level of } \\
\text { Significance }\end{array}$ \\
\hline Originality & .64 & $<.01$ \\
Flexibility & .80 & $<.01$ \\
Fluency & .67 & $<.01$ \\
Elaboration & .85 & $<.01$ \\
\hline
\end{tabular}

Table (4) shows that the correlation coefficient for the four components of the test with a total score of the test ranged from .64 to .85 , and all in accepted values (Odeh, 2010). As such, the test has good evidence of the construct validity (Odeh, 2010). In general, the test is valid and reliable and can be used to measure creative writing components.

\section{Results}

In order to answer the research question, are there any statistically significant differences in creative writing skills between the control group and the experimental group attributed to the instructional strategy (online reflective journals vs. the conventional)?

The means and standard deviations of student's performance in experimental and control groups for the fourth components of creative writing (Originality, Flexibility, Fluency, and Elaboration) were extracted. Table (5) illustrates the means and standard deviations of the four components of creative writing components for the experimental group and control group in the pre-test and post-test of the creative writing test. 
Table 5. Summary Results of Means and Standard Deviation of Creative Writing Components for the Pre-test and Post-test

\begin{tabular}{|c|c|c|c|c|c|}
\hline \multirow{2}{*}{ Creative writing Sub-skills } & \multirow{2}{*}{ Group } & \multicolumn{2}{|c|}{ Pretest } & \multicolumn{2}{|c|}{ Post-test } \\
\hline & & Mean & Std. Deviation & Mean & Std. Deviation \\
\hline \multirow{2}{*}{ Originality } & Experimental & 3.150 & .544 & 4.200 & .385 \\
\hline & Control & 2.350 & .494 & 3.050 & .304 \\
\hline \multirow{2}{*}{ Flexibility } & Experimental & 2.850 & .351 & 4.233 & .487 \\
\hline & Control & 2.183 & .445 & 2.783 & .339 \\
\hline \multirow{2}{*}{ Fluency } & Experimental & 2.817 & .425 & 4.033 & .472 \\
\hline & Control & 2.367 & .414 & 2.783 & .364 \\
\hline \multirow{2}{*}{ Elaboration } & Experimental & 2.783 & .429 & 4.117 & .520 \\
\hline & Control & 2.383 & .387 & 2.733 & .450 \\
\hline
\end{tabular}

* The maximum score for each sub-skill of originality, flexibility, fluency, and elaboration is 5

Table 6. Results of MANCOVA Analysis for the Effect of Instructional Technique on Students' Performance in Creative Writing Components after Condoling the Effect of Pre-Test Scores

\begin{tabular}{|c|c|c|c|c|c|c|c|}
\hline Source & Creative writing Sub-skills & $\begin{array}{c}\text { Type III Sum } \\
\text { of Squares }\end{array}$ & Df & Mean Square & $\mathbf{F}$ & Sig. & $\begin{array}{c}\text { Partial Eta } \\
\text { Squared }\end{array}$ \\
\hline \multirow{2}{*}{ Technique } & Originality & 9.299 & 1 & 9.299 & 78.265 & .000 & .592 \\
\hline & Flexibility & 17.251 & 1 & 17.251 & 98.359 & .000 & .646 \\
\hline \multirow{5}{*}{ Error } & Fluency & 9.018 & 1 & 9.018 & 56.258 & .000 & .510 \\
\hline & Elaboration & 11.630 & 1 & 11.630 & 49.078 & .000 & .476 \\
\hline & Originality & 6.416 & 54 & .119 & & & \\
\hline & Flexibility & 9.471 & 54 & .175 & & & \\
\hline & Fluency & 8.657 & 54 & .160 & & & \\
\hline \multirow{3}{*}{ Total } & Elaboration & 12.796 & 54 & .237 & & & \\
\hline & Originality & 815.250 & 60 & & & & \\
\hline & Flexibility & 780.250 & 60 & & & & \\
\hline \multirow{6}{*}{ Corrected Total } & Fluency & 730.750 & 60 & & & & \\
\hline & Elaboration & 746.250 & 60 & & & & \\
\hline & Originality & 26.812 & 59 & & & & \\
\hline & Flexibility & 41.746 & 59 & & & & \\
\hline & Fluency & 33.746 & 59 & & & & \\
\hline & Elaboration & 26.183 & 59 & & & & \\
\hline
\end{tabular}

As we can see in Table (5), there are noticeable differences between the mean scores of the experimental group performance and the mean scores of control group performance in favor of the experimental group in the four creative writing components (i.e., Originality, Flexibility, Fluency, and Elaboration), as measured by creative writing test. In other words, the mean scores of experimental group performance are higher than the mean scores of the control group in the four creative writing components.

To investigate the significance of the performance differences between the two groups in the four creative writing components, a one-way multivariate analysis of covariance (MANCOVA) was conducted to investigate the effects of instructional strategy (online reflective journals vs. conventional) in the combined four creative writing components, after controlling the effect of the pre-test scores.

In order to evaluate the significance of multivariate analysis, Hotelling's Trace statistic was applied. The results revealed a statistically significant effect of instructional technique (reflective journals vs. conferential) on the combined four creative writing sub-skills $(F(4,25)=$
49.128, Hotelling's Trace $=3.853$, partial Eta square $=$ $0.794, P<0.01$ ). The partial eta squared value of 0.794 represented that $79.4 \%$ of the variance in the combined variable (the four creative writing components together) could be attributed to the instructional technique.

Further, in order to investigate which creative writing component students in the experimental group and control group significantly differed in their creative writing performance, follow up Univariate analysis was conducted to investigate the effects of the instructional technique on student's performance in the four creative writing components. Table (6) shows that students in experimental and control groups are different in their creative writing performance in originality, flexibility, fluency, and elaboration sub-skills $(p<.01)$. As such, online reflective journals technique enhanced students' performance in originality, flexibility, fluency, and elaboration.

To investigate the effect size (partial eta squared) of instructional technique on students' creative writing performance in originality, flexibility, fluency, and elaboration components, the partial eta squared values were $.592, .646, .510$, and .476 for originality, flexibility, 
fluency, and elaboration sub-skills, respectively. This implies that the instructional technique explained $59.2 \%$, $64.6 \%, 51 \%$, and $47.6 \%$ of the variance in the four creative writing components.

Furthermore, adjusted creative writing components mean for experimental and control groups have been extracted. Table (7) presents the means and standard deviations for experimental group and control group performance in creative writing sub-skills, before and after controlling for pre-test scores. As it is evident from Table (7), virtually there are differences between the experimental group and the control group remains after differences in pre-test scores are controlled.

To investigate the effect of instructional strategy on the combined creative writing components, mean scores, and standard deviation of students' performance in experimental and control groups for the combined creative writing components were extracted. Table (8) illustrates the mean and standard deviation of the combined creative writing components for the experimental and control groups.

It is clear from Table (8) that there is a noticeable difference between the mean score of experimental group performance and the mean score of control group performance in favor of the experimental group in the combined creative writing components, according to the instructional technique (online reflective journals vs. conventional). In other words, the mean score of experimental group performance is higher than the mean score of the control group in the combined creative writing components (Total score of the creative writing components).

To test the significant difference in the combined creative writing components mean score between the experimental and the control groups, after controlling the effect of pre-test scores, one-way analysis of covariance (ANCOVA) was employed. Table (9) illustrates the summary results of ANCOVA.

Table 7. Adjusted and Unadjusted Group Means and Variability for Creative Writing Components Using Pre-Test Scores as a Covariate

\begin{tabular}{ccccccc}
\hline \multirow{2}{*}{ Creative writing sub-skills } & \multicolumn{2}{c}{ specific } & \multicolumn{2}{c}{ Adjusted Means } & \multicolumn{2}{c}{ Unadjusted Means } \\
& information Group & Mean & S.E & Mean & Std \\
\hline \multirow{2}{*}{ Originality } & Experimental & 4.212 & .080 & 4.200 & .385 \\
& Control & 3.038 & .080 & 3.050 & .304 \\
& Flexibility & Experimental & 4.308 & .097 & 4.233 & .487 \\
& Control & 2.708 & .097 & 2.783 & .339 \\
& Fluency & Experimental & 3.987 & .093 & 4.033 & .472 \\
& Control & 2.830 & .093 & 2.783 & .364 \\
& Elaboration & Experimental & 4.082 & .113 & 4.117 & .520 \\
& Control & 2.768 & .113 & 2.733 & .450 \\
\hline
\end{tabular}

*The maximum score for each sub-skill of originality, fluency, and elaboration is 5

Table 8. Summary Results of Mean and Standard Deviation of the Combined Creative Writing Components.

\begin{tabular}{ccccc}
\hline \multirow{2}{*}{ Group } & \multicolumn{2}{c}{ Pretest } & \multicolumn{2}{c}{ Post-test } \\
& Mean & Std. Deviation & Mean & Std. Deviation \\
\hline Experimental & 11.600 & 1.423 & 16.583 & .821 \\
Control & 9.283 & .858 & 11.350 & 1.138 \\
Total & 10.442 & 1.650 & 13.967 & 2.816 \\
\hline
\end{tabular}

Table 9. Results of ANCOVA Analysis for the Effect of Instructional Technique on Students' Performance in the Combined Creative Writing Components after Condoling the Effect of Pre-test Scores

\begin{tabular}{ccccccc}
\hline Source & Type III Sum of Squares & Df & Mean Square & F & Sig. & Partial Eta Squared \\
\hline Pre-test & .202 & 1 & .202 & .203 & .654 & .004 \\
Technique & 195.799 & 1 & 195.799 & 196.094 & .000 & .775 \\
Error & 56.914 & 57 & .998 & & & \\
Total & 12172.000 & 60 & & & & \\
Corrected Total & 467.933 & 59 & & & & \\
\hline
\end{tabular}


Table (9) shows that the mean score of the experimental group in the combined creative writing components is significantly higher than the mean score of the control group $(\mathrm{F}(1,58)=196.094 ; \mathrm{p}<.01 ;$ Partial eta squared $=.775)$. The partial eta squared, .775 , implies that $77.5 \%$ of the variance in the combined creative writing sub-skills could be attributed to instructional technique. As such, online reflective journals technique enhanced students' performance in the combined creative writing components.

Furthermore, the adjusted mean scores of the combined creative writing components for the experimental and control groups have been extracted. Table (10) presents the means and standard deviations for the experimental group and control group performance in the combined creative writing components, before and after controlling for pre-test scores. As it is evident from Table (10), virtually there is a difference between the experimental group and control group on the combined creative writing components remains after the differences in pre-test scores are controlled.

Table 10. Adjusted and Unadjusted Group Means and Variability for the Combined Creative Writing Components Using Pre-Test Scores as a Covariate

\begin{tabular}{c|c|c|c|c}
\hline \multirow{2}{*}{ Group } & \multicolumn{2}{|c|}{ Adjusted Means } & \multicolumn{2}{c}{ Unadjusted Means } \\
\cline { 2 - 5 } & Mean & S.E & Mean & STD \\
\hline Experimental & 16.525 & .224 & 16.583 & .821 \\
\hline Control & 11.408 & .224 & 11.350 & 1.138 \\
\hline
\end{tabular}

\section{Discussion}

This study examined the effectiveness of using online reflective journals on Birzeit University students' creative writing. The research study sought statistically significant differences in creative writing skills attributed to writing online reflective journals. The statistical analysis of the data revealed that there was a significant difference between the mean scores of the students of the control group and the experimental group on their creative writing post-test in favor of the experimental group. The results also indicated that there was a difference in the experimental group pre and post-test, where the mean of their post-test scores 16.583 was higher than that of the pre-test scores 11.600 . Henceforth, the online reflective journals had a significant role in enhancing students' creative writing main skills (originality, fluency, flexibility, and elaboration).

Based on the observed improvements of the students' creative writing skills (originality, fluency, flexibility, and elaboration), the researcher made some justifications on the effectiveness of using this instructional strategy. In this learning experience of writing online reflective journals, the students were offered several and frequent opportunities to practice writing through writing and sharing their online reflective journals on a closed group established for this particular purpose on the Messenger.

A potential justification for the improvement of creative writing skills could be attributed to the well-organized process of application of the instructional strategy. The students were taught how to write reflective journals. They were asked to write online reflective journals on themes related to the topics they learned in their textbook and share these journals on a Messenger group frequently. The students had the opportunity to read each other's reflective journals, discuss the ideas and the themes in their classmates' reflective writing, give suggestions for further improvements, and praise the excellent ideas and styles. These stages of writing, sharing, reading others' reflective journals, reflect openly on them, and suggest new topics for further journals. These activities helped students to be truly engaged in reflective writing, which has helped improve their creative writing. The researcher was keen to read the students' online reflective journals once they post them on the group and highlight the strong sides and the weak points to improve next time. This helped students improve their work and keep enthusiastic while writing. Moreover, the students were well-informed that their online reflective journals would not be graded and would not affect their grades in the course so that they could unleash their creativity in writing without holding any concerns of grades.

Another important factor that the researcher believed had helped was the secure, free, enjoyable, and interactive environment that was established first in the classroom and was also reflected in the atmosphere of the group on Messenger. The researcher, also the teacher, was careful in addressing the weak points in a way that helped the students deal with their weaknesses confidently and eagerly and seek to be improved. The students' choices and suggested topics were always welcomed and accepted with a high spirit. This safe environment encouraged the students to be creative and innovative and it had created a fun and social atmosphere. The researcher was keen to make her students use only English in interacting and commenting on their work and their classmates' online reflective journals. The researcher intended to improve their writing and their communicative skills in English, which had an impact on the naturalness and smoothness of writing.

Furthermore, the researcher encouraged her students to reflect on recent and current issues they have witnessed and have affected their lives in one way or another. Students wrote reflecting on their personal experience in the e-learning during the coronavirus crisis. They had elaborated in their reflective journals how they lived this period, the challenges, the bright sides, the e-learning new experience, and how they would respond differently in similar future conditions. This has granted their online reflective journals a special taste of authenticity and has connected them with daily life and students' common concerns and worries. The researcher believed that the 
coronavirus crisis and the lockdown have added special positive impacts on the online reflective journals. After being locked at homes and being deprived of face-to-face interaction with each other and with their teacher, this instructional strategy of reflective writing has gained more importance and has become more meaningful for them to be creative in presenting original ideas and thoughts related to their new daily conditions. It has also encouraged them to write more and more and to elaborate on the different experiences they faced. They also became more flexible in presenting their ideas and accepting their classmates' thoughts and feelings. Moreover, the students' tendency to express themselves has improved as they found this strategy a way to breathe out their fears, concerns, and hopes.

\section{Conclusions}

Based on the discussion of the results of this study, the following conclusions were extracted:

- The online reflective journals were an effective way to improve creative writing.

- Online reflective journals have shown positive impacts on improving students' abilities to originate new and novel ideas.

- Online reflective journals have shown satisfying results concerning enhancing students' abilities to expand their ideas and elaborate on them.

- Online reflective journals have improved students' fluency.

- Online reflective journals helped make students more flexible in presenting their ideas in writing.

- Writing an online reflective journal can be used to improve students' basic writing skills.

- This strategy has worked well during the e-learning period and distance learning as it improved students' communicative skills and enhanced using English in a non- academic context.

\section{Recommendations}

Based on the findings and the conclusion, the researcher recommends the following to be taken by EFL instructors at universities, EFL teachers at schools, EFL textbook designers, and researchers.

- EFL instructors at universities and EFL teachers at schools should enhance the writing skill in general and creative writing in particular by using online reflective journals as a tool to increase students' creativity and their tendency towards writing.

- EFL instructors and EFL teachers at schools should give their students the freedom to choose topics to write about as this will increase their enthusiasm towards reflective writing and can make this process more authentic and natural.
EFL instructors and EFL teachers at schools should make great use of social media means e.g. Facebook, Whatsapp, Messenger, etc. in diversifying their pedagogical methods in teaching English and help students to get engaged in learning outside the classroom.

- EFL instructors and EFL teachers at schools should always give constructive feedback to their students as this can encourage students to work and improve their writing and help increase their self -confidence and establish a friendly learning environment.

- EFL instructors and EFL teachers at schools should pay more attention to the peer assessment as a tool to transform to more learner-centered learning, to construct strong relations among students, and make students more aware of their paramount role in the learning process.

- EFL instructors and EFL teachers at schools should consider online reflective journals as an effective strategy to communicate with their students, especially during e-learning and distance learning. This strategy can help teachers keep in touch with their students and make good progress in learning English.

- EFL textbook designers should integrate reflective journals as a basic component in teaching writing and improving students' creativity,

EFL textbook designers can also recommend reflective journals as a valid tool of authentic assessment in teaching the English language.

- EFL textbook designers should take in mind the strong dominance of social media in students' lives and try to make good use of that for the sake of learning English beyond the classroom and to promote students' creative skills in writing.

- Researchers could benefit from the outcomes of this study. They could do further research and studies on how to investigate online reflective journals to improve learning other skills in English. These skills may include writing skills and reading comprehension. They can also investigate the potential effectiveness of online reflective journals in teaching and learning other subjects and topics, and scrutinize students' degrees of understanding and comprehension of the learning material.

\section{REFERENCES}

[1] Andrusyszyn, M.A, and Davie, L. (1995). Facilitating Reflection through Interactive Journal Writing in an Online Graduate Course. Journal of Distance Education. P 103-126.

[2] Annamalai, N., \& Jaganathan, P. (2017). Exploring students' reflective writing on Facebook. The EuroCALL Review, 
25(2), 3-17.

[3] Barbot, B., Tan, M., Randi, J., Santa-Donato, G., and Grigorenko, E. (2012). Essential skills for creative writing: Integrating multiple domain-specific perspectives. Thinking Skills and Creativity 7, (209-223).

[4] Boden, M. (2001). Creativity and knowledge. In A. Craft, B. Jeffrey, \& M. Leibling (Eds.), Creativity in education (pp. 95-102). London Continuum Publishing

[5] Boden, M. (2001). Creativity and knowledge. In A. Craft, B. Jeffrey, \& M. Leibling (Eds.), Creativity in education (pp. 95-102). London Continuum Publishing.

[6] Bolin, E S. (1990). Helping student teachers think about teaching: Another look at Lou. Journal of Teacher Education, 41(1), 10-20.

[7] Bolton, G. (2005) Reflective Practice: Writing and Professional Development (2nd Edition) (London, Sage, p. 3)

[8] Branch, W. T. (2010). The road to professionalism: Reflective practice and reflective learning. Patient Education and Counseling, 80(3), 327-332.

[9] Brookes, I. and Marshall, M. (2004). Good Writing Guide. NewYork: Harrap Publishers Ltd. Cambridge University Press.

[10] Chandio, J. H., Khan, H. M. A., \& Samiullah, M. (2013). Condition of creative writing in the north and south Punjab. Pakistan Journal of Commerce and Social Sciences (PJCSS), 7(2), 321-330.

[11] Chen, N. S., Wei, C. W., Wu, K. T. \& Uden, L. (2009). Effects of high-level prompt and peer assessment on online learners' reflection levels. Computers \&Education, 52(2), 283-291.

[12] Chen, S., \& Zhou, J. (2010). Creative writing strategies of young children: Evidence from a study of Chinese emergent writing. Thinking Skills and Creativity, 5(3), 138-149.

[13] Chen, S., \& Zhou, J. (2010). Creative writing strategies of young children: Evidence from a study of Chinese emergent writing. Thinking Skills and Creativity, 5(3), 138-149.

[14] Cramar, L. (2003). The Nature of Creative Writing. New York, Addison.

[15] Cristopher, E. (1996). Teaching creative writing in elementary school (ERIC Document Reproduction Service No: ED391182).

[16] Davies, E. (1995). Reflective Practice: A Focus for Caring. Journal of Nursing Education 34(4), 167-174.

[17] Dewey, J. (1933). How We Think: A Restatement of the Relation of Reflective Thinking to the Educative Process. Boston Process. Boston, MA: Houghton Mifflin Company.

[18] Donovan, M. (2007). Creative Writing Skills vs. Talent. Writing Forward.

[19] Dyment, J. E., and T. S. O’Connell. (2011). Assessing the Quality of Reflection in Student Journals: A Review of the Research. Teaching in Higher Education 16 (1): 81-97.

[20] Emig, J. (1977). Writing as a model of learning. College Composition and Communication, 28(2), 122-128.
Retrieved April 25, 2019, from JSTOR database.

[21] Essex, C. (1996). Teaching creative writing in the elementary school. ERIC Digest.

[22] Farrah, M. (2012). Reflective Journal Writing as an Effective Technique in the Writing Process. An - Najah Univ. J. Res. (Humanities). 26(4), 999-1025.

[23] Hedge, T. (2000). Teaching and Learning in the Language Classroom, Oxford University Press.

[24] Houston, W.R. (1988) Reflecting on reflection in teacher education In H.C. Waxman (ed.), Images of reflection in teacher education. Papers presented at a National Conference on Reflective Inquiry in Teacher Education. TX: Houston https://www.britannica.com/science/attitude-psychology

[25] Hubbs, D. L., and Brand, C. F. (2005). The Paper Mirror: Understanding Reflective Journaling. Journal of Experiential Education 28: 60-71.

[26] Hyland, K. (2002). Teaching and Researching Writing. Harlow: Longman.

[27] Kaplan, D. E. (2019). Creativity in Education: Teaching for Creativity Development Creativity Development. Psychology, 10, 140-147. https://doi.org/10.4236/psych.201 9.102012

[28] Karuri, A. (2012). Sample Reasoning Paper on Developing Creative Writing Skills English. Premium writing service.

[29] Kelly, C., and Gargagliano, A. (2001). Writing from within. New York, USA, Cambridge University Press.

[30] Killion, J. P., \& Todnem, G. R. (2001). A Process for Personal Theory Building. Educational Leadership, 48(6), 14-16.

[31] Klages, A. M. \& Clark, J. E. (2009). New worlds of errors and expectations: Basic writers and digital assumptions. Journal of Basic Writing, 28(1), 32-49.

[32] Kolb, D. A. (1984). "Experiential learning: Experience as the source of learning and development". Englewood Cliffs. NJ: Prentice-Hall.

[33] Krol, C. A. (1996). Pre-service teacher education students' dialogue journals: What characterizes students' reflective writing and a teacher's comments? Paper presented at the Annual Meeting of the Association of Teacher Educators, St. Louis, MO.

[34] Larkin, S. (2009). Socially mediated metacognition and learning to write. Thinking Skills and Creativity, 4(3), 149159.

[35] Lew, M.D.N., \& Schmidt, H.G. (2011). Self-Reflection and Academic Performance: Is There a Relationship? Advances in Health Sciences Education, 16(4).

[36] Liao, M. Z., \&Wong, C. T. (2010). Effects of dialogue journals on L2 students' writing fluency, reflections, anxiety, and motivation. Reflections on English Language Teaching, 9(2), 139-170..

[37] McGuire, L., Lay, K., \& Peters, J. (2009). Pedagogy of reflective writing in professional education. Journal of the Scholarship of Teaching and Learning, 9(1), 93-107. 
[38] McLoughlin C. \& Lee M. (2007). Social software and participatory learning: pedagogical choices with technology affordances in the Web 2.0 era. Retrieved $24^{\text {th }}$, January 2020 from

http://www.ascilite.org.au/conferences/singapore07/procs/ mcloughlin.pdf

[39] Nettle, D. (2009). The evolution of creative writing. In S. B. Kaufman, \& J. C. Kaufman (Eds.), The psychology of creative writing (pp. 101-116). New York.

[40] Randolph, P. T. (2011). Using Creative Writing as a Bridge to Enhance Academic Writing. In Perren, J. M., Losey, K., Popko, J., Perren, D. O., Piippo, A., \& Gallo, L. (Eds.), MITESOL Proceedings (Book 2, pp. 70-83). Ann Arbor: Michigan Teachers of English Speakers of Other Languages.

[41] Risko, V. J., Roskos, K., \& Vukelich, C. (2002). Prospective teachers' reflection: Strategies, qualities, and perceptions in learning to teach. Reading Research and Instruction, 41, $149-176$

[42] Rodgers, C. (2002). Defining reflection: Another look at John Dewey and reflective thinking. Teachers College Record, 104, 842-866.

[43] Root, R., \& Steinberg, M. (1999). The fourth genre: Contemporary writers oflon creative nonfiction. Boston: Allyn \& Bacon.

[44] Rusli, M., \& Sutopo, H. (2019). Development of
Visualization Scoreboard for Four Disciplines Execution Visualization of Journal Publication on Mobile Devices. International Journal of Computer Theory and Engineering, 11(6).

[45] Schon, D. A. (1987). The reflective practitioner: How professionals think in action. New York: Basic Books.

[46] Schon, Donald A. (1983). The Reflective Practitioner: How Professionals Think in Action. New York, NY: Basic Books.

[47] Shanahan, T., MacArthur, C. A., Graham, S., \& Fitzgerald, J. (2006). Relations among oral language, reading, and writing development. Handbook of writing research, 171-183.

[48] Shulman, L. (1987). Knowledge and teaching: Foundations of the new reform. Harvard Educational Review, 57(1), 122 .

[49] Sidek, E. A. R., \& Yunus, M. M. (2012). Students' experiences in using blogs as learning journals. Procedia-social and behavioral sciences, 67, 135-143.

[50] Starko, A. (2005). Creative in the Classroom. $3^{\text {rd }}$ ed. London: Lawrence Erlbaum.

[51] Sumsion, J., \& Fleet, A. (1996). Reflection: Can we assess it? Should we assess it? Assessment \& Evaluation in Higher Education, 21(2).

[52] Torrance, E. P. (1966). Torrance tests of creative thinking. Princeton, New Jersey: Personnel Press. 